\title{
HUBUNGAN FREKUENSI KONSUMSI GLUTEN DAN KASEIN DENGAN STATUS GIZI ANAK
} AUTISME

\author{
Syifa Nala Fauziyah, Martha Ardiaria, Hartanti Sandi Wijayanti" \\ ${ }^{*}$ Departemen Ilmu Gizi Fakultas Kedokteran Universitas Diponegoro \\ Jln. Prof. H. Soedarto, SH., Semarang, Telp (024) 8453708, Email : gizifk@ undip.ac.id
}

\begin{abstract}
Background: Gluten Free Casein Free (GFCF) diet is most widely diet applied in autistic children as it affects hyperactivity or other autistic symptoms. However, it may impact on the adequacy of nutritional intake of autistic children.

Objective: To determine the correlation of gluten and casein consumption with nutritional status in autistic children. Methods: This was cross sectional study. Respondents were 34 autistic children recruited with consecutive sampling. Food intake was assessed using $3 \times 24$ hours food recall and Food Frequency Questionnaire (FFQ), physical activity level was collected through the Physical Activity Questionnaire for Children (PAQ-C). Anthropometric data were taken by using of digital scale and microtoise. Data were analyzed using descriptive and correlation tests.

Results: This study found that 44,1\% subjects were overnutrition. Average of gluten and casein consumption were $9 \pm 8,8$

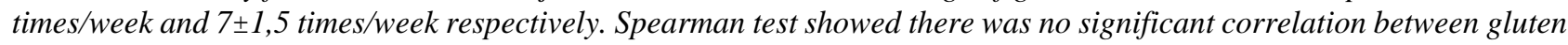
and casein consumption with nutritional status $(p=0,32 r=-0,17)$. Pearson test showed significant correlation of gluten and casein consumption with energy and fat adequacy $(p=0,049 r=0,34)(p=0,037 r=0,36)$.

Conclusion: Gluten and casein consumption was not significantly correlated with nutritional status in autistic children. Keywords: Autistic, gluten, casein, nutritional status
\end{abstract}

\begin{abstract}
ABSTRAK
Latar belakang: Terapi diet pada anak autisme yang paling banyak diterapkan adalah diet bebas gluten dan/atau kasein karena mampu memperbaiki gejala hiperaktifatau gangguan autisme lainnya. Hal ini juga dapat berdampak pada tingkat kecukupan asupan zat gizi anak autisme. Penelitian ini bertujuan untuk mengetahui hubungan frekuensi konsumsi gluten dan kasein dengan status gizi pada anak autisme.

Metode: Penelitian observasional desain cross sectional dengan jumlah responden 34 anak autisme yang diambil melalui metode consecutive sampling. Pengambilan data primer meliputi data asupan makanan dengan menggunakan metode food recall 3x24 jam dan Food Frequency Questionaire (FFQ), data aktivitas fisik dengan mengunakan kuisoner Physical Activity Questionaire for Children (PAQ-C), serta data antropometri melalui timbangan digital ketelitian 0,1 kg dan microtoise dengan ketelitian 0,1 cm. Analisis data dengan uji deskriptif dan uji korelasi.

Hasil: Masalah gizi yang banyak ditemukan pada responden adalah gizi lebih sebesar 44,1\%. Rerata frekuensi konsumsi

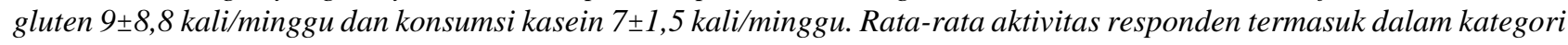
rendah. Hasil analisis uji Spearman menunjukkan tidak adanya hubungan bermakna antara frekuensi konsumsi gluten dan kasein dengan status gizi ( $p=0,32 r=-0,17)$. Namun, memiliki hubungan bermakna antara frekuensi konsumsi gluten dan/atau kasein dengan tingkat kecukupan energi $(p=0,049 r=0,34)$ dan lemak $(p=0,037 r=0,36)$ melalui uji korelasi pearson.
\end{abstract}

Simpulan: Frekuensi konsumsi gluten dan kasein tidak memiliki hubungan bermakna terhadap status gizi pada anak autisme.

Kata kunci: Autisme, gluten, kasein, status gizi

\section{PENDAHULUAN}

Autisme merupakan gangguan perkembangan disintegratif dengan ciri adanya kelainan perkembangan dan fungsi interaksi sosial, komunikasi, serta perilaku yang terbatas dan berulang, dimana tanda-tanda ini terlihat sebelum umur 3 tahun. Penelitian yang dilakukan Center for Disease Control and Prevention (CDC) di Amerika Serikat tahun 2013 menyatakan bahwa prevalensi autisme meningkat $0,15-0,20 \%$ per tahun di beberapa negara, termasuk Indonesia. Penelitian lain memperkirakan adanya peningkatan jumlah anak autisme di Indonesia mencapai 6.900 anak/tahun. ${ }^{1,2,3}$
Beberapa penelitian menyebutkan adanya masalah malnutrisi pada anak autisme, baik masalah gizi lebih maupun gizi kurang. ${ }^{1}$ Penelitian pada anak autisme usia 3-16 tahun yang mengalami status gizi lebih sebesar 40\%. ${ }^{1,4}$ Hal ini didukung dengan penelitian yang menyebutkan bahwa prevalensi obesitas pada anak autisme lebih tinggi dibandingkan pada anak normal, yaitu 30,4\% pada anak autisme dan 20,3\% pada anak normal. ${ }^{5}$ Penelitian lain menyatakan prevalensi anak autisme usia 5-20 tahun yang mengalami status gizi kurang mencapai $30 \%$ dan gizi lebih $23,3 \% .^{6}$ 
Kondisi anak autisme, jika peptida opioid yang bersumber dari makanan tinggi gluten dan kasein melewati membran usus permiabel akan masuk kedalam sistem saraf pusat. Hal ini dapat memberikan efek kepada neurotransmiter, sehingga muncul gejala fisiologis autisme. ${ }^{7,8}$ Oleh karena itu, muncul diet Gluten Free Casein Free (GFCF) yang sudah mulai diterapkan oleh sebagian orangtua anak autisme. Gluten adalah protein alami dalam kelompok jenis gandum, seperti tepung terigu, oat, barley. Kasein merupakan protein alami dalam susu dan olahannya, seperti keju dan yoghurt. ${ }^{9}$

Makanan sumber gluten yang masih banyak dikonsumsi oleh anak autisme adalah roti, mie, biskuit, bakso, sosis, wafer, dan makanan tinggi energi lain yang bersumber dari tepung terigu. ${ }^{10} \mathrm{Hal}$ ini jika disertai dengan kebiasaan aktivitas fisik yang rendah pada anak autisme, maka asupan energi yang masuk dalam tubuh akan disimpan dalam bentuk lemak. Simpanan lemak tubuh dalam jangka waktu yang lama mengakibatkan status gizi lebih. Anak autisme yang menerapkan diet GFCF dengan ketat tanpa disertai dengan makanan variatif yang mampu menggantikan zat gizi dalam makanan sumber gandum atau susu, akan berisiko gizi kurang. Konsumsi makanan yang sudah variatif namun adanya gangguan absorpsi dan metabolisme makanan yang dikonsumsi juga dapat mengakibatkan defisiensi zat gizi sehingga dalam jangka panjang anak mengalami gizi kurang. ${ }^{11}$

Adanya faktor pola makan yang idiosyncratic serta rendahnya aktivitas fisik, seperti isolasi sosial dan perilaku yang berulang-ulang pada anak autisme juga dapat mempengaruhi status gizi anak autisme. ${ }^{5}$ Maka, penelitian ini penting dilakukan untuk mengetahui apakah ada hubungan antara frekuensi konsumsi gluten dan/atau kasein dengan status gizi anak autisme.

\section{METODE}

Pengambilan data dilakukan di lima tempat, yaitu SLB Negeri Semarang, Sekolah Anargya, Yayasan Pembinaan Anak Cacat (YPAC), Yayasan Yogasmara, dan Komunitas LRD pada tanggal 22 Februari-31 Maret 2017. Jenis penelitian ini adalah observasional dengan desain cross sectional. Jumlah responden 34 anak berdasarkan perhitungan rumus uji korelasi dengan nilai $r=0,5$ yang diambil dengan metode consecutive sampling. Kriteria inklusi responden meliputi anak autisme berumur 6-15 tahun, bersedia menjadi responden dengan persetujuan orang tua serta tidak mengalami down syndrom. Kriteria eksklusi responden ini yaitu mengundurkan diri saat penelitian atau meninggal dunia.

Variabel terikat dalam penelitian ini adalah status gizi, yang dapat diketahui dengan melakukan pengukuran antropometri yang diklasifikasikan berdasarkan $Z$ score IMT/U. Alat antropometri yang digunakan adalah timbangan injak digital ketelitian $0,1 \mathrm{~kg}$ dan microtoise ketelitian $0,1 \mathrm{~cm}$. Klasifikasi status gizi berdasarkan $Z$ score IMT/U dibagi menjadi tiga yaitu gizi lebih $(>1 \mathrm{SD})$, normal $(\geq-2 \mathrm{SD} \mathrm{s} / \mathrm{d} \leq 1$ $\mathrm{SD})$, gizi kurang $\left(<-2\right.$ SD) ${ }^{12}$ Variabel bebas penelitian ini adalah frekuensi konsumsi gluten dan/atau kasein, yang diperoleh dengan menggunakan metode Food Frequency Questionaire (FFQ). Data pendukung penelitian ini adalah asupan responden yang diperoleh berdasarkan metode food recall $3 \times 24$ hours, dianalisis dengan menggunakan software nutrisurvey 2005. Angka kecukupan gizi makronutrien diketahui dengan membandingkan asupan aktual responden dengan perhitungan rumus energi, karbohidrat, lemak, dan protein. ${ }^{13}$ Klasifikasi tingkat kecukupan makronutrien yaitu berlebihan jika kecukupan zat gizi $\geq 120 \%$ total kebutuhan, dikatakan normal jika mencapai $80-119 \%$ total kebutuhan, dikatakan kurang jika $\leq 80 \%$ total kebutuhan. ${ }^{11}$ Data aktivitas fisik sebagai data pendukung diukur dengan menggunakan kuisoner Physical Activity Questionaire (PAQ-C). Klasifikasi aktivitas fisik berdasarkan nilai median skor aktivitas fisik yaitu jika skor < nilai median maka termasuk kategori tingkat aktivitas rendah. Jika skor $\geq$ nilai median maka termasuk kategori cukup dengan nilai median yang diperoleh adalah 18,3.

Analisis data untuk mengetahui hubungan frekuensi konsumsi gluten dan/atau kasein dengan status gizi menggunakan uji korelasi. (kemaknaan $\mathrm{p} \leq 0,05$ dengan derajat kepercayaan $95 \%$ ).

\section{HASIL PENELITIAN}

Responden pada penelitian ini memiliki distribusi jenis kelamin 29 laki-laki dan 5 perempuan dengan usia berkisar antara 6-15 tahun dengan ratarata 11 tahun.

Berdasarkan tabel 1. rerata Z-score responden adalah 0,6 SD (gizi normal), rerata frekuensi konsumsi gluten lebih tinggi dibandingkan dengan frekuensi konsumsi kasein. Rerata asupan makronutrien dalam kategori kurang, karena tingkat kecukupan asupan karbohidrat, lemak, dan protein $\leq 80 \%$ dari total kebutuhan. Aktivitas fisik rata-rata pada responden termasuk dalam kategori kurang, karena skor rata-rata < nilai median $(18,3)$.

Tabel 2. menunjukkan bahwa masalah gizi yang banyak ditemukan pada responden adalah gizi lebih. Responden lebih banyak memiliki frekuensi konsumsi gluten dan/atau kasein $\leq 14 \mathrm{x} /$ minggu, serta lebih dari $50 \%$ memiliki tingkat kecukupan asupan makronutrien dalam kategori kurang. Selain itu, ternyata tingkat aktivitas fisik responden juga sebagian besar dalam kategori rendah. 
Berdasarkan tabel 3. hasil analisis korelasi Spearman yang diperoleh menunjukkan nilai $p>0,05$ yang artinya tidak terdapat hubungan signifikan antara frekuensi konsumsi gluten dan/atau kasein pada status gizi anak autisme. Selain itu, hubungan tingkat kecukupan energi, karbohidrat, lemak, dan protein serta aktivitas fisik dengan status gizi juga tidak bermakna $(p>0,05)$.

Tabel 1. Karakteristik Responden

\begin{tabular}{lrrr}
\hline Karakteristik & Mean \pm SD/Median & Min & Maks \\
\hline Usia (tahun) & $11,2 \pm 2,2^{\mathrm{a}}$ & 6 & 14,5 \\
Status Gizi & & & \\
Z-score IMT/U (SD) & $0,6 \pm 1,7^{\mathrm{a}}$ & $-3,3$ & 3,7 \\
Frekuensi Konsumsi Gluten dan/atau Kasein & & & \\
Frekuensi Gluten (x/mingu) & $9^{\mathrm{b}}$ & 0 & 32 \\
Frekuensi Kasein (x/minggu) & $4^{\mathrm{b}}$ & 0 & 31 \\
Frekuensi Gluten dan Kasein (x/minggu) & $14^{\mathrm{b}}$ & 0 & 49 \\
& & & \\
Asupan & & & \\
Energi (kal) & & 35,5 & 91,6 \\
Karbohidrat (gr) & $60,3 \pm 15,8^{\mathrm{a}}$ & 5,3 & 99,5 \\
Lemak (gr) & $60,8 \pm 22,8^{\mathrm{a}}$ & 25,6 & 151,2 \\
Protein (gr) & $74,2 \pm 32,3^{\mathrm{a}}$ & 26,7 & 131,9
\end{tabular}

Aktivitas Fisik

Skor Aktifitas fisik

$18,2 \pm 3,6^{\mathrm{a}}$

12

27,5

${ }^{\mathrm{a}}$ Rerata, ${ }^{\mathrm{b}}$ Median, $I M T / U$ Indeks Massa Tubuh menurut Umur

Tabel 2. Gambaran Karakteristik Responden Berdasarkan Jenis Kelamin, Usia, Status Gizi, Makronutrien, Konsumsi Gluten dan Kasein, serta Aktivitas Fisik

\begin{tabular}{|c|c|c|}
\hline Karakteristik Responden & $\mathbf{n}$ & $\%$ \\
\hline \multicolumn{3}{|l|}{ Jenis Kelamin } \\
\hline Laki-laki & 29 & 85,3 \\
\hline Perempuan & 5 & 14,7 \\
\hline \multicolumn{3}{|l|}{ Kategori Usia } \\
\hline Anak & 11 & 32,4 \\
\hline Remaja & 23 & 67,6 \\
\hline \multicolumn{3}{|l|}{ Status Gizi } \\
\hline Gizi kurang & 3 & 8,8 \\
\hline Gizi normal & 16 & 47,1 \\
\hline Gizi lebih & 15 & 44,1 \\
\hline \multicolumn{3}{|c|}{ Frekuensi Konsumsi Gluten dan/atau Kasein } \\
\hline$\leq 14 \mathrm{x} /$ minggu & 20 & 58,8 \\
\hline$>14 \mathrm{x} /$ minggu & 14 & 41,2 \\
\hline \multicolumn{3}{|c|}{ Tingkat Kecukupan Asupan Energi } \\
\hline Kurang & 31 & 91,2 \\
\hline Cukup & 3 & 8,8 \\
\hline \multicolumn{3}{|c|}{ Tingkat Kecukupan Asupan Karbohidrat } \\
\hline Kurang & 27 & 79,4 \\
\hline Cukup & 7 & 20,6 \\
\hline \multicolumn{3}{|c|}{ Tingkat Kecukupan Asupan Lemak } \\
\hline Kurang/cukup & 30 & 88,2 \\
\hline Berlebihan & 4 & 11,8 \\
\hline \multicolumn{3}{|c|}{ Tingkat Kecukupan Asupan Protein } \\
\hline Kurang & 30 & 88,2 \\
\hline Cukup/berlebih & 4 & 11,8 \\
\hline \multicolumn{3}{|l|}{ Aktivitas Fisik } \\
\hline Kurang & 18 & 52,9 \\
\hline Baik & 16 & 47,1 \\
\hline
\end{tabular}


Tabel 3. Hubungan Frekuensi Konsumsi Gluten dan/atau Kasein, Kecukupan Makronutrien dan Aktivitas Fisik dengan Status Gizi Anak Autisme

\begin{tabular}{lccc}
\hline & & Nilai $\boldsymbol{p}$ & Nilai $\boldsymbol{r}$ \\
\hline Frekuensi Konsumsi & & $0,32^{\mathrm{c}}$ & $-0,17^{\mathrm{c}}$ \\
$\begin{array}{l}\text { Gluten dan/atau } \\
\text { Kasein }\end{array}$ & & \\
& & & \\
Tingkat Kecukupan & Energi & $0,60^{\mathrm{d}}$ & $-0,09^{\mathrm{d}}$ \\
Asupan & Karbohidrat & $0,37^{\mathrm{d}}$ & $-0,15^{\mathrm{d}}$ \\
& Lemak & $0,81^{\mathrm{d}}$ & $0,04^{\mathrm{d}}$ \\
& Protein & $0,36^{\mathrm{c}}$ & $-0,16^{\mathrm{c}}$
\end{tabular}

Aktivitas fisik

$0,73^{\mathrm{d}}$

$0,06^{\mathrm{d}}$

${ }^{\mathrm{c}} \mathrm{Uji}$ Spearman, ${ }^{\mathrm{d}} \mathrm{Uji}$ Pearson $p=p$ value $r=$ korelasi

Tabel 4. Hubungan Frekuensi Konsumsi Gluten dan/atau Kasein dengan Tingkat Kecukupan Asupan Makronutrien

Tingkat Kecukupan Asupan

\begin{tabular}{ccccccccc} 
& \multicolumn{2}{c}{ Energi } & \multicolumn{2}{c}{ Karbohidrat } & \multicolumn{2}{c}{ Lemak } & \multicolumn{2}{c}{ Protein } \\
& Nilai $\boldsymbol{p}$ & Nilai $\boldsymbol{r}$ & Nilai $\boldsymbol{p}$ & Nilai $\boldsymbol{r}$ & Nilai $\boldsymbol{p}$ & Nilai $\boldsymbol{r}$ & Nilai $\boldsymbol{p}$ & Nilai $\boldsymbol{r}$ \\
\hline Frekuensi & $0,049^{\mathrm{d}}$ & $0,34^{\mathrm{d}}$ & $0,58^{\mathrm{d}}$ & $0,09^{\mathrm{d}}$ & $0,037^{\mathrm{d}}$ & $0,36^{\mathrm{d}}$ & $0,65^{\mathrm{c}}$ & $0,07^{\mathrm{c}}$
\end{tabular}

Konsumsi

Gluten

dan/atau

Kasein

${ }^{\mathrm{c} U j i}$ Spearman, ${ }^{\mathrm{d}} \mathrm{Uji}$ Pearson $p=p$ value $r=$ korelasi

Berdasarkan tabel 4. frekuensi konsumsi gluten dan/atau kasein berhubungan dengan tingkat kecukupan energi dan lemak $(\mathrm{p}<0,05)$. Semakin sering frekuensi konsumsi gluten dan/atau kasein, maka akan semakin tinggi tingkat kecukupan energi dan lemak, hal ini karena nilai korelasi positif.

\section{PEMBAHASAN}

Status gizi responden yang termasuk dalam malnutrisi mencapai 52,9\% dengan rincian kategori gizi lebih $44,1 \%$ dan hanya $8,8 \%$ masuk dalam kategori gizi kurang. Hal ini sesuai dengan penelitian yang menyebutkan prevalensi gizi lebih pada anak autisme cukup tinggi yaitu mencapai $21,8 \%$ $58,8 \% .^{1,4,14,15}$ Berdasarkan teori, anak autisme memiliki pola perilaku yang stereotype/repetitive dengan kategori aktivitas fisik rendah. Selain itu kondisi anak autisme yang picky eaters (memilihmilih makanan), kesulitan menerima makanan baru, luapan kekesalan atau kemarahan (tantrum), dan gerakan mengunyah sangat pelan ${ }^{2}$ serta sensori anak autisme dalam penerimaan jenis dan tekstur tertentu yang terbatas.

Penelitian ini mencatat anak autisme yang benar-benar menerapkan diet ketat atau tidak konsumsi sumber gluten dan/atau kasein berjumlah 5 anak. Sejumlah 4 anak memiliki status gizi normal dan 1 anak status gizi gemuk. Berdasarkan FFQ rerata frekuensi konsumsi gluten (9x/minggu) lebih tinggi dibandingkan dengan frekuensi konsumsi kasein (7x/minggu). Hal ini sesuai dengan penelitian yang menyebutkan bahwa konsumsi sumber makanan gluten lebih sering dibandingkan dengan konsumsi sumber makanan kasein. ${ }^{4}$ Akses sumber makanan gluten lebih sering tersedia disekitar lingkungan responden dibandingkan dengan sumber makanan kasein, sehingga ketika tanpa pengawasan orangtua, maka responden dapat mengonsumsi sumber gluten, seperti biskuit.

Berdasarkan uji Spearman menunjukkan tidak adanya hubungan bermakna antara frekuensi konsumsi gluten dan/atau dengan status gizi anak autisme $(p=0,32 \quad r=-0,17)$. Meskipun demikian, antara frekuensi konsumsi gluten dan kasein dengan kecukupan energi terdapat hubungan yang bermakna $(p=0,049 r=0,34)$. Hal ini menunjukkan korelasi positif yang berarti semakin tinggi frekuensi konsumsi gluten dan/atau kasein maka akan semakin tinggi tingkat kecukupan energi. Responden yang memiliki frekuensi konsumsi gluten yang tinggi, jenis makanan sumber gluten yang sering dikonsumsi yaitu jenis yang memiliki kandungan lemak yang tinggi, seperti gorengan. Hal ini didukung dengan adanya hasil analisis korelasi pearson yang menunjukkan adanya hubungan bermakna antara frekuensi konsumsi gluten dan/atau kasein dengan tingkat kecukupan lemak ( $p=0,037 r=0,36$ ). Semakin tinggi konsumsi gluten dan/atau kasein maka tingkat kecukupan lemak juga semakin tinggi. Hal yang perlu menjadi perhatian bahwa semakin tinggi konsumsi gluten dan/atau kasein, maka semakin tinggi tingkat kecukupan asupan energi dan asupan lemak. Adanya 
peningkatan asupan energi dan lemak tanpa disertai dengan tingkat aktivitas fisik yang cukup, maka lemak dalam tubuh secara terus menerus akan disimpan dan dapat menimbulkan risiko obesitas. ${ }^{16}$

Beberapa faktor lain yang mempengaruhi status gizi anak autisme diantaranya pola makan yang tidak biasa pada anak autisme dan aktivitas fisik yang rendah. ${ }^{5,17}$ Sebagian besar anak autisme memiliki pola makan yang idiosyncratic, yaitu variasi makanan yang rendah, tidak menerima tekstur makanan tertentu dan sulit untuk menerima jenis makanan baru. ${ }^{2}$ Variasi makanan responden pada penelitian ini sebesar 26,5\% memiliki variasi makan yang rendah, yaitu hanya nasi dan lauk hewani dalam sehari. Sejumlah 73,5\% Responden lainnya terdapat variasi sayur maupun lauk nabati yang disajikan dalam bentuk yang sama selama sehari, baik yang membatasi gluten dan/atau kasein maupun yang tidak membatasinya.

Mayoritas anak autisme memiliki alergi terhadap sumber makanan gluten dan/atau kasein, akan tetapi tidak semua anak autisme alergi terhadap sumber makanan gluten dan/atau kasein. ${ }^{18}$ Orangtua merasa ketidakefisiensinya penerapan diet GFCF terhadap perbaikan gejala anak autisme seperti sikap stereotype/repetitive, dan masalah komunikasi sosialnya sehingga tidak menerapkan diet GFCF. Diet GFCF hanya dapat diterapkan pada beberapa anak autisme yang benar-benar alergi atau intoleran terhadap gluten dan/atau kasein yang mampu memperbaiki perubahan perilaku anak autisme. ${ }^{19,20}$ Sebagian besar orangtua membolehkan responden mengonsumsi makanan ringan yang mengandung gluten, seperti biskuit, wafer, dan mie yang berbahan dasar tepung terigu. ${ }^{21}$

Berdasarkan hasil penelitian, hal yang perlu diperhatikan adalah adanya faktor lain yang mempengaruhi status gizi anak autisme. Pola perilaku anak autisme yang khas, yaitu isolasi sosial dan memiliki perilaku yang berulang-ulang, sehingga kategori aktivitas mereka masuk dalam kategori rendah. Hal ini dapat ditunjukkan pada hasil penelitian ini bahwa anak autisme yang malnutrisi memiliki aktivitas fisik kurang sebesar $61,1 \%$. Pola perilaku sedentary, seperti menonton televisi, games yang sering dilakukan pada responden dapat meningkatkan prevalensi obesitas. ${ }^{22}$ Penelitian lain dengan studi kohort menunjukkan bahwa anak dapat menjadi obesitas karena pola aktivitas fisik. ${ }^{23}$

\section{SIMPULAN}

Penelitian ini menunjukkan bahwa tidak terdapat hubungan bermakna.antara frekuensi konsumsi gluten dan/atau kasein dengan status gizi

\section{SARAN}

Bagi orangtua yang memiliki anak autisme dianjurkan untuk menerapkan pola makan anak yang variatif guna mencapai kecukupan zat gizi, serta mempertimbangkan ada tidaknya alergi untuk mengurangi picky eater pada anak autisme.

\section{UCAPAN TERIMA KASIH}

Terima kasih atas segala dukungan, bantuan, dan doa yang diberikan kepada pihak-pihak yang berpartisipasi dalam penelitian ini

\section{DAFTAR PUSTAKA}

1. Pratiwi RA, Dieny, FF. Hubungan skor frekuensi diet bebas gluten bebas kasein dengan skor perilaku autisme. Journal of Nutrition College. 2014; 3(1): 4047

2. Ramadayanti S, Margawati A. Perilaku pemilihan makanan dan diet bebas gluten bebas kasein pada anak autisme. Journal of Nutrition College. 2013; 2(1): 3543

3. Putra I, Sumitra IN, Yasa Kecemasan orangtua pada anak autisme. Jurnal Keperawatan. 2011; 2 (1): 159

4. Mujiyanti DM. Tingkat pengetahuan ibu dan pola konsumsi pada anak autisme di kota Bogor. IPB Scientific Repository. 2011; 1: 22-23

5. Curtin C, Anderson SE, Must A, Bandini L. The prevalence of obesity in children with autism: a secondary data analysis using nationally representative data from the national surey of children's health. BMC Pediatric. 2010; 10: 11

6. Rahayu S.Gambaran perilaku picky eater, pola makan dan status gizi anak autisme di SLB Negeri Semarang. Jurnal Biomedika UMS. ISSN 2085-8345.2016; 1:3

7. McCandless J. Children with starving brains: a medical treatment guide for autism spectrum disorder. 4th edition. Florida: Bramble Books; 2009. p.132-142

8. Ratnawati, H. Leaky gut sebagai penyebab gangguan gastrointestinal pada ASD. Jurnal Kesehatan Masyarakat. 2003; 2(2): 51

9. Chasanah R,Yuliati R, Rahayu T. Gambaran Pola Konsumsi Makanan Mengandung Gluten dan Kasein serta Kaitannya dengan Gejala Perilaku Khas Anak Autisme di Sekolah Khusus Autisme di DIY. Prosiding Seminar Nasional Pendidikan dan Penerapan MIPA: Fakultas MIPA UNY ;2012

10. Mantos A, Ha E, Caine N, Burzminski N. Effect of the gluten free/casein free diet on the nutritional status of children with autism. 2011; 9:111

11. Gibson RS. Principles of Nutritional Assesment. New York (US) : Oxford University; 2005. p.665

12. Hayatti E. Hubungan antara tingkat kecukupan gizi, aktivitas fisik dan pola konsumsi pangan bebas gluten dan kasein dengan status gizi anak penyandang autis di kota Bogor.IPB Scientific Repository.2015; 4: 5

13. Mahan K. Krause's Food \& The Nutrition Care Process 14th Edition.Washington:Elsevier; 2017.p.23-24

14. Curtin C, Bandini LG, Perrin EC, Tybor DJ, Must A. Prevalence of overweight in children and adolescents 
with attention deficit hyperactivity disorder and autism spectrum disorders: a chart review. BMC Pediatric. 2005;5:48

15. Ramadhani K. Tingkat Pengetahuan terhadap Pola Makan Anak Autisme pada Ibu di Keluarga Sejahtera dan Ibu di Keluarga Prasejahtera. Jurnal Gizi Klinik Indonesia.2013; 9(3): 11

16. Kruger HS. Stunted girls have greater subcutaneous fat deposits: What type of intervention can improve the health of stunted children? Journal of Nutrition. 2005; 21:1153-1155

17. Provost B, Crowe TK, Osbourn PL, McClain C, Skipper BJ. Mealtime behaviors of preschool children: comparison with autism spectrum disorder and children with typical development. Physical and Occupational Therapy in Pediatrics. 2011; 30(3): 220-233

18. Whiteley P, Haracopos D, Knivsberg A, Reichelt K, Parlar S, Jacobsen J,et.al. The scanbrit randomized, controlled, single blind study of a gluten and casein free dietary intervention for children with autisme spectrum disorders. Nutritional neuroscience. 2010; 13:87-100

19. Mulloy A, Lang R, O’Reilly M, Sigafoos J, Lancioni $\mathrm{G}$, Rispoli M. Addendum to gluten free and casein free diets in treatment of autism spectrum disorders: a systematic review. Research in Autism Spectrum Disorder. 2011; 5: 86-88

20. Marcason W. What is the current status of research concerning use of gluten free, casein free diet for children diagnosed with autism?. Journal of The American Dietetic Assosiation.2009; 109(3): 572

21. Anwar T. Protein intake is inversely associated with abdominal obesity in a multi-ethnic population. The Journal of Nutrition. 2005; 135:1196-1201

22. Swinburn B, Egger G. Preventive strategies against weight gain and obesity. Obesity Review.2002; 3:289-301

23. Hu FB, Li TY, Colditz GA, Willett WC, Manson GE. Television watching and other sedentary behaviours in relation to risk of obesity and type 2 diabetes mellitus in women. JAMA.2003; 289: 1785-1791. 